\title{
The Learning of Cooking in the Light of the Social Practices and the Organizational Aesthetics
}

\author{
Lídia Cunha Soares ${ }^{\dagger}$ \\ Faculdade Adventista Paranaense - IAP \\ Marcelo de Souza Bispo $\mathbf{\Omega}^{\mathbf{2}}$ \\ Universidade Federal da Paraíba
}

\begin{abstract}
The aim of this article was to analyze the learning process of cooking in the two regional restaurants from the Brazilian northeast in the light of social practices and the organizational aesthetics. Thereby, it carried out a qualitative research drawn on an aesthetic approach. The construction of empirical data was through the mehod of zooming in and zooming out, operationalized through participant observation, informal conversations, and semi structure interviews. The analysis were carried out using aesthetics categories related to the cooking practice. The results show that the cooking learning occurs through the use of perceptive faculties along with collective aesthetic judgements constituting the social practice of cooking. Conclusions highlight that the cooking practice implies on the taste making that represents a sensible knowledge resulted from what is touchable, visible, hearing, smelled, and tasted.
\end{abstract}

Keywords: Organizational Aesthetics; Situated learning; Cooking; Practice; Sensible knowledge.

*Author for correspondence:

\footnotetext{
$\dagger$. Faculdade Adventista Paranaense - IAP PR-317 - Zona Rural, Ivatuba - PR, CEP: 87130-000, Brasil

E-mail: lidiacsoares@gmail.com
}

\footnotetext{
$\Omega$. Universidade Federal da Paraíba Cidade Universitária. CEP: 58051-900. João Pessoa - PB, Brasil

E-mail: marcelodesouzabispo@gmail. com
} 


\section{INTRODUCTION}

ince the 1980s, organizational theory and management studies have been admitting the presence of aesthetics as something relevant in organizational life. Rationalist ideas, which marked the tradition of organizational analysis, were minimized, and aesthetics could present itself as important for the study of organizational phenomena. Thus, subjective aspects related to organizational phenomena - that they were slightly considered, or even avoided, by organizational researchers, as those related to what is tacit and hardly verbalized or measured gained new understanding with the adoption of organizational aesthetics. It has come to be admitted that the real world of organizations is made up of colors, smells, textures, flavors, rhythms, sounds, erotic, beautiful and ugly elements that cause fascination or repulsion on the part of those who interact with this context (WOOD JR., CSILLAG, 2001; REED, 2007; STRATI, 1992, 2007a).

At the same time, since the 1980s, the organization studies have presented an extensive debate about the nature of learning and organizational knowledge. In tow, the current known as Practice-Based Research (PBR) has presented a relevant contribution to the understanding of how the processes of learning and generation of knowledge occur in contexts of high subjectivity. This contribution is due to the rejection that the organizational phenomena are based only by rational ideas, which conceive learning and knowledge as purely cognitive, or even as mere variables, well-defined that do not allow procedural and subjective understanding of these two phenomena. Under the epistemology of practices (MIETTINEN, SAMRA-FREDERICKS, YANOW, 2009; GHERARDI, 2014a; BISPO, 2015; SANTOS, ALCADIPANI, 2015), phenomena that involve learning and knowledge gain more procedural contours with emphasis on collective construction between human and nonhuman actors (LATOUR, 2005).

The notion of practice, inspired by the seminal reflections of Aristóteles (1999), Giddens (1984), Bourdieu (1977, 1990), Certau (1998), among others, influences on how the idea of practice has been approached more recently by authors like Schatzki (2001), Reckvitz (2002), Gherardi (2006, 2012), Nicolini (2013), Shove, Pantzar and Watson (2012), Antonacopoulou (2015) and Bispo (2013b, 2015). Reflections and debates on the notion of practice have been used in various fields of knowledge such as philosophy, anthropology, psychology, education and organizational studies (MIETTINEN, SAMRA-FREDERICKS, YANOW, 2009; AZEVEDO, 2013). Among the main themes of interest, the epistemology of practice has contributed to the understanding of phenomena such as what is called "social", the nature of organizations and organizational processes, understanding of learning processes and knowledge, training aspects of innovation of various kinds, educational environment, business strategy etc.

Despite the existence of various chapters in the approaches that make up the "theories of practice" or the "practice-based research", it is possible to say that, in general, a social practice can 
be understood as a set of activities which acquire meaning in a situated context and that it is repeated many times and even socially recognized. Thus, a practice is the result of daily collective bargaining and is sustained through its repetition over time. It is a way of organizing the world through human and non-human elements (GHERARDI, 2006). Bispo (2013b) explains that practices are the ways of "doing" of a society, they are related to social construction and reproduction, to the processes of learning and generation of knowledge in the context of a given group.

Therefore, it is assumed in this study that learning and knowledge take place in practice (SCHATZKI, 2001; RECKVITZ, 2002; GHERARDI, 2001，2006,2009，2014a; 2014b; MIETTINEN, SAMRA-FREDERICKS, YANOW, 2009; BISPO, 2015) in which "learning" and "knowing" necessarily involve prominent aspects of organizational aesthetics (STRATI, 1992, 2000, 2007a, 2007b, 2010, 2014). Thus, it is possible to justify the debate and the study of learning and knowledge from the perspective of aesthetics in gastronomy, which in this case, is also part of organization studies. The context of this research were two regional restaurants, in a capital of the Northeast region of Brazil, and the choice was due to the opportunity to study regional cuisine, which is heavily loaded with "practical" aspects involved in a very peculiar culture, with gastronomy being a relevant activity for tourism and the local economy. Thus, "cooking as practice" emerged from the field of research as a contextual phenomenon, heavily loaded with tacit and aesthetic knowledge, that is, sensible (STRATI, 2007b). The cooking practice is marked by the intense use of the sensory-perceptive faculties, taste, hearing, feeling, smelling and seeing. The perceptive faculties are used to aesthetically judge textures, aromas, flavors, sounds and movements peculiar to cooking (IPIRANGA; LOPES; SOUZA, 2016, FINE, 1996). From the methodological point of view, we based this research on an aesthetic approach (STRATI, 2007a) and we used as a means of access to empirical data to participant observation zooming in and zooming out type (NICOLINI, 2009).

Thus, in this work, the cooking practice expressed by situated learning, knowledge as practice and organizational aesthetics is relevant due to the theoretical contributions to the fields of organization studies, more specifically organizational learning and gastronomy (RINK, 2012; SOARES, BISPO, 2014; LOPES, SOUZA, IPIRANGA, 2014;FERREIRA; GODOY, 2015). The study also brings a practical contribution in that it extends the possibilities of thinking how to promote the advancement in the training of future professionals of restaurants. Thus, the objective of this study is to analyze the process of cooking learning In two regional food restaurants in a capital of the Brazilian Northeast in the light of social practices and organizational aesthetics.

In order to carry out the presented objective, this work is divided in five moments, besides this introduction. The first presents the social learning in the situated perspective, the second presents the notion of sensible knowledge and organizational aesthetics (STRATI, 1992, 2007a, 2007b), the 
third presents the methodological course adopted, the fourth presents the results of the research and the fifth brings the conclusions about the study.

\subsection{Social learning in situated perspective}

For a long time, organizational learning was predominantly understood as cognitive and behavioral, that is, centered on the individual (GHERARDI, 2006). Learning was basically presented in two ways: as acquisition of individual knowledge or as individual development. Learning as acquisition of individual knowledge studied how the human being stored concepts, skills, and behaviors to then say how one could add value to the company through that ability. Learning as an individual development, even with a constructivist approach, maintains as a static and cognitive bias, which compromises the understanding of how this phenomenon occurs in the interaction with other people (FLACH, ANTONELLO, 2011).

Recognizing the need for an approach that focuses more on the social character of learning, since organizational work is characterized as a social activity, an emerging debate has taken place on the international stage. Learning has been understood in a social perspective based on the idea of practice. Learning as practice does not only encompass activities and routines, but also considers the important role of language, material and cultural artifacts, the social and tacit situated interactions of social actors within a network of relationships (FLACH, ANTONELLO, 2011). Therefore, social learning expressed as a practice relates to doing and knowing (BISPO, 2013a; AZEVEDO, 2013). This doing and knowing only happens action. In other words, "action creates knowledge formed in and through action itself' (GHERARDI, 2014a, p.7).

Social learning in the perspective of practice is understood as an activity in which "learning" happens through the so-called "legitimate peripheral participation" process. This process happens when a beginner, that is, someone who is starting to develop a group activity, moves from the periphery of a practice to its center. Legitimate peripheral participation contributes to the understanding of the process of socialization that occurs in learning as a practice, that is, how one learns to become a practitioner of a particular sociocultural practice (LAVE, WENGER, 1991; WERGER, 2000). Table 1 summarizes the main concepts that involve situated learning.

According to Nicolini (2013), legitimized peripheral participation is as a specific and identifiable social process in which the learner effectively engages in continuous practice, a specific form of participation that implies partial responsibility for the final product. Through this process, the learner gains access to knowledge that is socially sustained in in the transmission of a practice, as well as acquiring legitimacy with the other members of the community who sustain the practice. 
Table 1 - Situated learning concepts

IMPORTANT CONCEPTS

It is the process by which a new entrant in a community seeks to achieve legitimacy within a group. The individual starts as a peripheral and not legitimized participant, and should learn the "rules of the game" in order to Legitimate peripheral participation gain space to naturally gain a more central position with more responsibility in the group in order to establish the condition of effective and legitimate membership. This is not a formal process, but full of informal tacit elements (LAVE, WENGER,1991).

Is a network formed by all actors participating in the practice (LAVE, WENGER,1991).

Community of practice

Set of attributes and skills that beginners should learn to become practitioners

Learning Curriculum of a specific community (LAVE, WENGER,1991).

A type of tacit and symbolic content that reveals the modus operandi of a

Situated curriculum particular group is to understand how a group "works" through what is often not said, but is perceived. The learning of this curriculum is fundamental to gain legitimacy in a group (GHERARDI, 2006, 2012; BISPO, 2013a).

Source: Adapted by LAVE, WENGER, 1991; GHERARDI, 2006, 2012; BISPO, $2013 \mathrm{a}$.

This is not a merely cognitive, but social process that involves engagement, interaction, inclusion and identity development.

In this way, when interacting with an organization, each professional has their learning curriculum learned in their professional training (e.g. cooking), useful mainly for technical development, as well as for their repertoire of experiences. The situated curriculum however, is all that is new (norms, systems, contents of the organization, symbolic aspects) that the novice needs to learn to become a member of a specific community (for example, being a cook in a specific restaurant).

In this sense, the practice assumes different forms of knowledge and actions. In this study, cooking is a practice endowed with details that sometimes is considered to be an art (HEGARTY, O’MAHONY, 2001). Cooking (from Latin coquere) literally means preparing food by the action of fire (VIEIRA, 1878). As a professional practice, exercised in an organizational environment, it presents as main actors, respective and hierarchically presented, the chef, the cook and the kitchen assistant. The first is responsible for the creation and execution of the dishes and for managing the kitchen. The second has specific knowledge of culinary techniques (MENESES, 1997). The third, the kitchen assistant, is assigned the responsibility of general support, proceed with the prepreparation (mise en place), cleaning, sanitizing, organization and preparation of simpler foods (INFOJOBS, 2014).

Cooking and culinary practices have received interest from researchers who study everyday work practices. Internationally, we highlight Fine's (1996) research who focused on investigating how students learn and are professionally taught how to cook. The author observed that aesthetics at 
work is important for the learning process in kitchens of four restaurants. In the Brazilian scenario, more specifically in the organization studies, Lopes, Souza and Ipiranga (2014) developed a research in a small restaurant. They understood that the actors' knowledge about an organization is sensible experienced by the pathos of the sensible and expressed by aesthetic categories. These categories form a kind of web which represents the expression of apprehension about the organization.

Ferreira and Godoy (2015), when studying individual and collective learning of kitchen and hall workers in three restaurants of a German ethnic club, observed that the creation of knowledge takes place while the adult learners carry out their activities. They focused on the "doing" of restaurants" practitioners live and experience in relation to the work they perform. In the cultural and social context, learning occurs through social interaction. Ipiranga, Lopes and Souza (2016) advocate that there is a greater knowledge than the rational logic for the understanding of a gastronomic organization. The understanding of organizational life is permeated by images, metaphor and symbols. These results reinforce the ideas advocated by Soares and Bispo (2014), who in their theoretical article explain that organizational aesthetics presents itself as a valuable approach for understanding gastronomic organizations, since in these organizations the corporate day-to-day is marked by the constant use of taste, touch, smell, sight, hearing and aesthetic judgment.

Thus, studies on cooking and culinary practices in gastronomic organizations have evidenced that the perceptual faculties and aesthetic judgments are relevant in the process of social learning to boost the interaction of humans and non-humans. In addition, a gastronomic organization can be better understood by using an aesthetic approach, given that it favors corporeality, the sensible knowledge and aesthetic judgments that are crucial both for work as for the assessment by the clients of the result of the work performed.

\section{SENSIBLE KNOWLEDGE AND THE STRATI's ORGANIZATIONAL AESTHETICS}

Aesthetics is a field of philosophy that studies art, especially beauty, but it is not just that (WOOD JR., CSILLAG, 2001; RODRIGUES, 2008). The concept emerged in Ancient Greece and was related to artistic representations. However, it is also studied by arts, architecture, design and psychology (WOOD JR.; CSILLAG, 2001). In the context of organization studies, the influence of aesthetics comes from the studies of the philosophers Alexander Gottlieb Baumgarten, between 1735 and 1750, and Giambattista Vico in 1725 (STRATI, 2000). It was later developed by the seminal works of Antonio Strati and Pasquale Gagliardi in the 1990s (LEAL, 2002). In Brazil, aesthetics were introduced by the works of Thomaz Wood Jr. and Paula Csillag (2001) as well as Raimundo Leal $(2002,2007)$. Since then, it has been used to study different themes and organizational contexts such as creativity (LEAL, 2007), marketing (BRANDÃO, 2008), 
gender (BASSO; PAULI; BRESSAN, 2014), learning (BERTOLIN; CAPPELLE; BRITO, 2014), knowledge management (WILLERDING; KRAUSE; LAPOLLI, 2016), travel agencies (BISPO, 2014), gastronomic organizations (LOPES; SOUZA; IPIRANGA, 2014, SOARES; BISPO, 2014; IPIRANGA; LOPES; SOUZA, 2016) and manicures work (GALLON; BITENCOURT; VIANA; ANTONELLO, 2016).

The enthusiastic theorists of the approach of the organizational aesthetics as a theoretical and methodological base defend the organizational understanding beyond the rational human dimension because they advocate that the human being is endowed with a sensitive aesthetic dimension and that the organizational processes are affected by them. Thus, when experiencing the daily work, the subject does not only use the cognitive, but the aesthetic dimension as well. This indicates that one can be suspicious that organizational decisions are taken in a purely rational, legal, ethical and cognitive way Practitioners are the result of the appropriation of their body makes through the use of the senses and aesthetic judgment, which is educated by the social context (STRATI, 1992, 2007a, 2014; LEAL, 2002; BERTOLIN; CAPPELLE; BRITO, 2014; LOPES; SOUZA; IPIRANGA, 2014, BISPO, 2014; SOARES; BISPO, 2014; GALLON; BITENCOURT; VIANA; ANTONELLO, 2016).

Strati's organizational aesthetics $(1992,2000,2007 \mathrm{a}, 2007 \mathrm{~b}, 2010,2014)$ is expressed by the perception of the five senses: hearing, sight, touch, smell, taste, and the ability we have to make the aesthetic judgment about what we experience. This judgment is expressed through what we do when we come into contact with the world through the body, that is, when we perceive things through our body, we can judge whether what we feel is "good", "bad", "appropriate", or whether what is perceived is "ugly" or "beautiful"; and it may involve us or leave us indifferent. Therefore, to make an aesthetic judgment is to judge something from what we feel. Thus, it should be emphasized that this perception is not only characterized by the physical perception of the sense organs, but the expression of faculties established and socially educated (STRATI, 2007a), that is, what is already assumed to be "good" or "bad", "beautiful" or "ugly", etc.

The description of this judgment is called the aesthetic category. Each category corresponds to the expression of a type of aesthetic perception, allowing a better understanding of organizational life. According to Strati (1992), it is possible to identify up to 64 aesthetic categories, among which, for example, those described in Table 2.

The aesthetic categories are adjectives adopted by the organizational actors to express their perception in relation to the daily life in the organization and are part of the researcher's experience as it immerses in organizational life, as well as when participating in the day-to-day activities of the organization under investigation. Therefore, they contribute explicitly to the understanding of organizational knowledge because they are the expression of that knowledge (STRATI, 2007a). 
Table 2. Aesthetic categories

\section{AESTHETIC CATEGORIES}

Beauty represents luminosity, symmetry, ability to attract or deceive, persuasive force.

The sacred involves the legendary and fantastic phenomena that represent that which is wonderful, inexplicable, invisible, unusual, unforgettable, exceptional and divine.

The sublime is the product of the nobility of a soul that clings to holiness and purity. It values moral rectitude, dignity and nobility of spirit in organizational life.

The picturesque may refer to rough and rustic landscapes, which are bizarre and unusual, as well as to describe a colorful, pleasant and unusual daily action that evokes aesthetic emotions and relate to other family landscapes.

The comic is the expression of the grotesque in organizational life. The irony, laughter, sarcasm, sense of humor.

The agogic categories are related to rhythm. They focus on the whole rhythm of organizational activities, with music, ordering the sequence of dance steps, movements in a painting, as well as peak and off working times.

The ugly is the absence of the beautiful. It causes a malaise, it is dangerous, aggressive, shocking, impure, asymmetrical, unpleasant and disgusting.

Source: Adapted by Taylor, Hansen, 2005; Strati, 2000; 2007a; Rink, 2012.

Organizational knowledge - which we will call here practical knowledge or "knowing in practice", and which resembles the tacit knowledge of Polanyi (1966), but differs from Knowledge Management (ORLIKOWSKI, 2002) - it is a kind of knowledge that we possess, but it is difficult to explain. It is that knowledge that people have, understand that they have, can put into practice, but they cannot explain how they do it being difficult to express in words.

The knowing-in-practice is the result of everyday action involving human and non-human actors. It is a moment knowledge, for the situation, provisional in essence, and it happens continuously according to the interpretation of the lived experience, it occurs in different contexts and is mediated by social relations. Thus, it cannot be understood as something stable and permanent, because it is nowhere, it is not materialized in files and systems (ORLIKOWSKI, 2002). Knowing in practice occurs when the individual becomes a participant in a community of practice (BISPO, 2013a).

In organizations, it is possible to perceive several aesthetic manifestations judged as positive or negative. Aesthetic knowledge relates to the beauty of what can be seen, with the fascination exerted when coming into contact with a certain work, with the organizational environment that pleases, the sense of well-being, with what is heard. But also with displeasure experienced on a number of occasions, such as gossip, the bad smell coming from inside or outside the organizational environment, which the individual experiences and positioning oneself about it (STRATI, 2007a).

Studies show that aesthetic knowledge is perceived while people work (EWENSTEIN, WHYTE, 2007) and happens during action. Studying aesthetics in organizations, in life and in the corporate day-to-day is to raise the aesthetic knowledge that happens in practice (GHERARDI, 2001; STRATI, 2006). The practice approach allowed new ways of studying aesthetic knowledge and learning in organizations by creating the opportunity to understand the role of the senses in knowing and practicing (STRATI, 2007b). 
It is from the perspective of an aesthetic knowledge that sensible knowledge is born, that is, the one that makes possible to know deeply through the perceptive faculties that involve the aesthetic experience. Through the activation of the aesthetic judgment, one arrives at the sensible knowledge, which is empirical and not reflective. Sensible knowledge is that which is perceived, judged, produced and reproduced through the senses (GHERARDI, 2001; GHERARDI, NICOLINI, STRATI, 2007; STRATI, 2007a, 2007b; BISPO, 2013b).

Sensible knowledge is formed from what we may call taste- making, which, in turn, is "a situated activity resting on learning and knowing how to appreciate specific performances of a practice" (GHERARDI, 2013, p. 110). This process of learning and refining a practice is what promotes taste-making. According to Bispo (2013b), taste-making "is the process by which the members of a community seek to improve their practices through the sensible knowledge". By contacting a community, individuals participate and negotiate among themselves the practices that are produced, reproduced and influenced by personal and aesthetic knowledge, negotiated through the aesthetic categories (GHERARDI, 2013).

\section{METHODOLOGICAL COURSE}

For the accomplishment of an aesthetic research, we need the researcher to have a new conscience, focused on the sensible and involving an "aesthetic style" (STRATI, GUILLET MONTOUX, 2002; STRATI, 2010, 2014b). For Strati (2014, p. 179) in an "aesthetic style" the researcher:

chooses a theme, style, and object of analysis according to their taste and personal preferences for method and theory;(b) activates sensory faculties and aesthetic judgment to immerse oneself in the texture of organizational interactions and while they act and interact.

In this sense, upon entering the field we used the eyes, smell, hands, ears, palate and our aesthetic judgment in the collection of data. The choice for the field was due to the relevance of the restaurants in the production of regional food in the researched city.

Our impressions on the field were influenced by our sensible knowledge of restaurants. Thus, we made use of multisensoriality in data collection, activating all our perceptual-sensory faculties. However, as explained by Strati (2014), it is not possible to become completely free of rationality to ensure scientific rigor from the methodological procedures described below and which serve to systematize the knowledge produced.

It is important to mention that by assuming the epistemology of social practices (MIETTINEN et al., 2009), the interaction between the researcher and context is fundamental, not seeking generalizations, to understand learning from our engagement with the researched context. In this 
research, we consider the cooking practice as the unit of analysis because it was the most evident during the immersion in the field. We used different techniques for field access such as participant observation, informal conversations, two semi-structured interviews with restaurant owners (FLICK, 2009) and imaginary participatory observation (STRATI, 2010, 2014b).

The observations were carried out in two restaurants of regional food of a northeastern capital, between June 2014 and January 2015, with a total of forty-six visits, with twenty in Restaurant I (RI) and sixteen in Restaurant II (RII), totaling approximately one hundred and seven hours in the field.

The observations were made within the kitchen of the restaurants where it was possible to visualize the work performed and the development of the practice, as well as observing the cooks and kitchen assistants. Table 3 presents the characteristics of the actors who performed cooking as practice. The names assigned to the respondents are fictitious.

We made the observations guided by the method of zooming in and zooming out (NICOLINI, 2009). First, for zooming in, we adopted guiding questions about practice, The interaction of human participants; norms, institutional rules and conditions and corporal aspects. In September 2014, the first writing of the data was carried out in a grouped form, which made enabled us to identify the practice. The data were analyzed aesthetically and thematically so that the set of activities loaded with aesthetic content became prominent. Then, we proceeded to zooming out following the intermediaries, following the relations between similar activities identified in the two restaurants. Still during the observations, all that was observed was noted down in a field notebook and later transcribed into MS Word, and these notes originated a total of 42 sheets.

While transcription was performed, imaginary participatory observation was also carried out. This occurred as follows: while we read the field notes, activating the aesthetic-sensible judgment we remembered the speeches, smells, images, tastes, sounds, judgments made in loco and represented the organizational atmosphere. Thus, we gradually sought to "return" to the research environment in an imaginary way, observing what did not become aesthetic and perceptive at the time we were in the field. This strategy served to improve the analysis of raw data through this process of imaginary participatory observation (for a better understanding of the method, see STRATI, GUILLET MONTOUX, 2002; STRATI, 2010, 2014b). It was with this strategy that we proceeded to the evocative interpretive analyzes. That is, reading the raw data and enriching them with aesthetics evoked us in the field of research. This process was carried out whenever we reached the field, as guides Strati (2014b), so collecting and analysis are carried out jointly. Gradually, field experiences gained more consistency in order to be analyzed. Doubts that remained became questions that were brought to the field again through questioning in later informal conversations 
Table 3. Human actors participating in the research

\begin{tabular}{|c|c|c|c|c|}
\hline $\begin{array}{l}\text { Fictitious } \\
\text { name }\end{array}$ & Role & Tempo de restaurante & Formação & Experiência \\
\hline $\begin{array}{l}\text { Restaurant } \\
\text { time }\end{array}$ & Cook & 1 year and 10 months & Full High School & $\begin{array}{l}\text { Had no prior experience, } \\
\text { joined the company as a } \\
\text { general service assistant. }\end{array}$ \\
\hline Mateus & Cook & 3 months & $\begin{array}{l}\text { Ongoing tech course in } \\
\text { gastronomy }\end{array}$ & 13 years \\
\hline Daniela & Kitchen assistant & 1 year & High School & Had no previous experience. \\
\hline Silvia & Kitchen assistant & 8 months & Full High School & Had no previous experience. \\
\hline Flavia & Kitchen assistant & 12 months & Incomplete high school & 6 years' experience. \\
\hline Amanda & Kitchen assistant & $\begin{array}{l}1 \text { year and } 9 \text { months } \\
\text { in house }\end{array}$ & Elementary School & 4 years' experience. \\
\hline Luiz & Maître & 4 years & - & - \\
\hline
\end{tabular}

Source: Authors, 2015

on new restaurant visits. The data of the set of activities loaded with esthetic contents important for the learning process were grouped as the "cooking practice" in the final writing of the results.

During the research, a semi-structured interview was also conducted with one of the owners of each establishment. Table 4 presents the characteristics of these interviewees.

The interview questions were also constructed during the field observation period. The analyzes were carried out in an evocative and interpretative manner according to the analysis of the set of activities and the aesthetic contents identified in the observation that form the cooking practice. As recommended by Strati (2007a,2014), we resorted to the experiences of organizational dynamics and preserved the contradictions, ambiguities and constructed an open text (STRATI, 2007b). "So those who read and/or hear the results should activate their own perceptive-sensory faculties and sensible-aesthetic judgment in order to interpret and make sense" (STRATI, 2014, p. 179) out of the results.

\section{RESULTS}

The most prominent practice in the organizations studied was "cooking", chosen as it is an indispensable aspect of gastronomic organizations and for, quite clearly, expressing the learning, generation and transmission of knowledge that is involved in aesthetic aspects and sensible knowledge. Regarding the learning of the cooking practice, the observed actors were cooks and kitchen assistants in restaurants I and II. We understand that the practice of cooking is a result of the set of activities and similar learning processes in the two restaurants. Thus, we chose to construct a single report about cooking learning as a practice in general and not how this practice behaves specifically in RI or in RII. The account of the observations was done in the first person singular, 
Table 4. Interview with restaurant owners

\begin{tabular}{lccc}
\hline Interviewee & Date & Duration & Observations \\
\hline OWNER OF RI & $12 / 12 / 2014$ & 26 minutes and 10 seconds & $\begin{array}{c}\text { Family restaurant, the owner's son, ma- } \\
\text { nage (financial, purchasing, stock and } \\
\text { person) o restaurant. }\end{array}$ \\
OWNER OF RII & $25 / 11 / 2014$ & 39 minutes 38 seconds & Partner, runs the restaurant. \\
\hline
\end{tabular}

Source: Authors

and the analyzes in the first person plural, since the field observations reported here, were carried out by the first author of this article. RI was founded in 2010 and its action niche is the regional beach food (fish and seafood). It receives the influences of the region as well as contemporary and European cuisine in its recipes.

It was the first restaurant specialized in this niche in the city. The restaurant's lounge is decorated in nautical theme, a place of its own aesthetic that wishes to evoke feelings related to the sea. On the walls, nautical charts, many details in wood, antique furniture, marine artifacts (barge, compass, anchor, armillary sphere and rudder), is a picturesque environment that evokes the internal environment of a large ship. The restaurant's cook is (in the context of the research) Raíssa, the assistants are Daniela, Silvia and the Maître Luiz.

The RII was founded in 1994, and in 2004 two brothers became partners and acquired the restaurant. In 2011, they rented the new building, a planned space for the restaurant. RII has as its niche the regional food of the countryside - sertão (wilderness region) and cariri, typical northeastern. The restaurant's lounge is picturesque in its decor, it evokes the porch of a farmhouse or that of a ranch house or a roadside restaurant. With rustic architecture (apparent bricks and wood) and artifacts (miniatures of animals - oxen, horses and goats, lamps and woodcuts). The restaurant's cook is (research participant) Mateus and assistants Amanda and Flávia.

The aesthetic understanding of both restaurants refers to the picturesque, ambiance and rustic architecture, decorated according to a purpose (sea and countryside), pleasant places and it seeks to evoke aesthetic emotions familiar to customers. The category of the beautiful is also felt, beauty is everywhere and in every detail.

\subsection{Learning and sensible knowledge of cooking as practice in the light of Strati}

As for cooking as a practice, while Raissa taught Silvia how to prepare a dish, she explained the gastronomic activity when she said "I add fish sauce too because it gets tastier; we should add only shrimp sauce, but... I put a bit of fish sauce, too", taught what Silvia needed to "know-do" to join the cook community. This was possible because of the interaction. 
We realize that shared knowledge in a discursive way is collective. We emphasize that when Silvia asked if the dish was being executed correctly, it corresponds to a social response to the norms of practice in order to make the dish more "yummy" (GHERARDI, 2006; GHERARDI, 2014a).

By appropriating cooking as a practice, the cook learns doing while a beginner practices the situated curriculum, but the cook does not always do it in the way that is considered correct by the cook community. This perception is justified by questions such as "Is this so?" "Is that okay?" When the novice can, with the aid of more experienced practitioners, reproduce the practice and thus learn, one continues to legitimize themselves. When one cannot learn by general observation alone, more experienced member exemplifies the activity being shared. For example, I noticed when Artur said to Flávia, "Be careful when turning the plate so it the potato chips does not slather", Flávia continued to do the same thing. Artur stopped everything he was doing, approached Flávia and set the plate himself so as not to slather the potatoes and in the end said, "See how it is done?" (FIELD NOTES, AUGUST, 2014). The cooking learning as a practice happens through interaction, "know-do" and observation. Often times a more experienced practitioner demonstrates the how to do", and the novice learns through direct observation.

Another time, I saw Flávia teaching Mateus (novice) to beat the meat. "You have to hit the meat like that", said Flávia. Artur came closer and continued to teach Mateus while beating hard with a hammer on the meat. "We hit it until it softens, you see?" Mateus hit the meat and asked Artur to touch the meat to check its tenderness. He said: "I know, it's like this, right?" Then, Flávia left and left the novice alone performing the activity. I watched intently, the novice doing the way Artur and Flávia taught; Mateus was hitting, then stopped to think, he called Artur and asked, "Is it good?", then he continued to hit it some more (FIELD NOTES, AUGUST, 2014).

The good to which Mateus refers to does not have an ethical sense, but an aesthetic sense, it is associated with doing the right. By doing what is considered correct by the cook community, he was seeking to fit into the situated curriculum in the restaurant where he worked. The good is an institutionalized standard through gastronomy as a daily practice and knowing how to do this good is, at the same time, to legitimize themselves in the community of cooks and to learn a specific aesthetic judgment. This aesthetic judgment had been learned in an aesthetic-sensorial way, which shows how the perceptive faculty is accurate and socially sophisticated (STRATI, 2007a). When one comes into contact with a new situation, the apprentice will then judge according to the situated context of the community of which one is a part of.

At one point, in the same Sunday observation, Luiz went into the kitchen to observe and approached Silvia and said loudly: "You're to be congratulated, you really are, you're ready to work at night, do you want to work nights?'. Silvia listened to everything while cooking, continued 
with her head lowered, ashamed, but with a calm countenance and answered in a low and timid tone: "No!". He kept talking "You really are to be congratulated!" Everyone in the kitchen observed the compliment and remain silent. As Luiz left the kitchen, I noticed that Silvia's countenance had changed, she now had a "laughter" on her lips and, at the same time, she seemed worried. I continued to watch Silvia for a few moments. She noticed that she was being watched, she raised her face and looked at me suspiciously, timidly. I offer a smile in approval, and she reciprocated (FIELD NOTES, AUGUST, 2014).

Before I left the restaurant that day, I went to talk to Luiz about his public compliment to Silvia, and asked him why he had been so emphatic.

Look, this girl, Silvia, she got here, we realize she has the ability to cook, so we're thinking of promoting her. She has developed well since she arrived here. Here it is so, if the person likes what they do, has skills, develops themselves, we will give more responsibility to the person. (...)She already does almost everything alone. She already sets whole dishes, she knows the recipes, she's very secure. We are thinking about putting her at the night shift, she will be very useful, she is very good (FIELD NOTES, AUGUST, 2014).

With regard to the work developed by Silvia, we realize that she is legitimizing herself in the community, she works confident, she performs the job of a kitchen assistant and receives more responsibility when the cook teaches her to prepare a dish that is a cook assignment. Corroborating with what Gherardi, Nicolini and Odella (1998) understand as the legitimate peripheral participation, when a novice starts to legitimize, one is able to perform satisfactorily a certain amount of activities. With legitimacy one becomes progressively independent, remaining in a state of readiness in which one is in charge of more and more complex tasks. Over time, the novice gains confidence, and the work group also trusts that one is able to perform the activities assigned to them.

It is pertinent to say that the "ability to cook" mentioned by Luiz refers to a sensible, personal knowledge that is socially legitimized, that is, an individual and at the same time collective knowledge, an aesthetic skill. In order to become a good cook, it is necessary to have the "ability" to cook. This perception is also shared by the owner of the RII when he states that in a days' work it is possible to see if the person has a "knack for the kitchen" (RII OWNER, INTERVIEW). This perception corroborates with the study by Strati (2007b) in which beginners are recruited based on their skills the moment they are beginning to learn. In this study, the ability of beginners is important for them to stay in the restaurant after the trial period, and thereafter to be promoted to cook. Thus the perceptual-sensorial capacity becomes important in the adoption of cooking as practice.

We emphasize that the ability to cook is an aesthetic ability, an individual exercise of interpretation developed by the set of perceptive faculties. Aesthetic-sensory ability is a kind of sensible and tacit knowledge (2007b). It is something that Polanyi (1962) describes as difficult to 
explain. Therefore, it is not possible to describe by means of scientific knowledge in the traditional positivist patterns of "rigor". It is not teachable nor learned formally.

In addition, something quite interesting that happens at all times is the synchronism, a sort of integrated work: the team is able to without talking, just looking, to work for a long time, it is something interesting, the interaction is complete and represents an organizational process (BISPO, 2015). They work for a long time in silent in a synchronized way. Synergy is perceived in the work environment; if a cook stops an activity, the other cook or kitchen assistant completes it. Everyone knows the recipes, even the kitchen assistants. If there is any doubt, they ask and continue. This greatly favors work practice as it allows multiple dishes to be set at the same time faster. On one occasion, I observed two cooks cutting the ingredients for a sauce, putting them all in the same pan. They can prepare the same dish together, two or three people at once (FIELD NOTES, AUGUST, 2014).

The synchronism (organization) of the kitchen, in addition to explaining how the cook community becomes a practitioner, expresses the specific rhythm characterization, constant and pleasant. Besides, the category of the sublime, the one that is closest to the beautiful, emphasizes the beauty of the work in its own order, the way the cook community relates to gastronomy, a different order from that which is prescribed by the organization, since it belongs to the cooks. This synchronism is a kind of engagement that expresses the greatness of work and is difficult to represent, because it refers to the aesthetic and the tacit of organizational life as well as highlighting the impalpable of organizational aesthetics (STRATI, 2007a, 2014).

Although there are occasions when the conflict is direct, the aesthetics of organizational life highlights the subliminal conflict perceived through the atmosphere of the organization (STRATI, 2014). One night I arrived in the kitchen of the restaurant and I noticed a very tense atmosphere, people were dissatisfied, there was an uncomfortable 'atmosphere', the kitchen felt strange, the silence was different, the people were different (FIELD NOTES, AUGUST, 2014). During the evening, it was not possible to perceive the reason for the change in the atmosphere. But episodes like these demonstrate that the aesthetics of organizational life cannot always be "seen" but it can be "felt", "experienced" by the organizational atmosphere. Whenever I entered the field, I could perceive how the "atmosphere" was, if it was calm, comfortable, if some conflict was in the "air", whether people were apathetic, angry, or happy. The organizational atmosphere shows the conflict, the power games, and the mistrust that are latent in organizational life (STRATI, GUILLET DE MONTOUX, 2002; GHERARDI, 2014b).

The tense atmosphere is experienced by the most varied conflicting situations and is, contained with the aesthetic category of the comic. The comic, the grotesque and the sarcastic are constantly used to minimize the charged atmosphere. As can be seen from the fragment of 
observation: "The kitchen remains tense, at dinner time, Júlio tries to make fun to relax, with every employee entering the kitchen he makes a joke. He jokes about the hunger, the size of the dish, with food preferences, ironically implies that some are overweight and that others are below it. "At some point, Júlio told me: it's all happening today! Then we have to spend time joking, because otherwise it is worse, we cannot stress out, we have to laugh" (FIELD NOTES, AUGUST, 2014).

The comic in the kitchen emerges in many moments. In the work groups, the games involve both work itself and the content around it. Thus, practitioners make fun with each other. The jokes not related to the strict moments of practice refer to the mental state of the practitioners and to the domino game that is played in the interval (in one of the restaurants during break time, after feeding, the kitchen staff play dominoes. Generally in the following days the "losers" are ironized). Curiously, the research and the researcher also appear in the witty sayings in the work environment. A manifestation that represents this analysis comes from the manifestation of one of the researched ones: "Hey, you're studying me because I'm crazy?". One explanation for this may be the very inconvenience caused by being observed. Thus, the witty sayings about me served me so that I could enjoy a more pleasant atmosphere while experiencing the annoyances of the field of research.

Besides, while cooking as practice happens, a component aspect is rhythm. The rhythm of the restaurant is also characterized as an agent of influence in synchronism. Depending on the rhythm of restaurant orders, the work harmony changes greatly. We must understand that the rhythm can be slow, busy and rushed. The slow rhythm is represented by few customers, few orders, and flow described as "weak", it becomes monotonous for practitioners. As described by Amanda, "it makes us sad... women... when there is little customer flow, it seems that time does not go by" (FIELD NOTES, AUGUST, 2014). The busy rhythm, a kind of continuous flow of work, is associated with pleasure, achievement in work, and utility. Understood as "very good", "it is good when there is a lot of work, it is bad when there are too few orders" (FIELD NOTES, SEPTEMBER, 2014), it expresses the constancy of a certain rhythm of "deal work". We emphasize that on busy days the kitchen is cheerful, the mood is light, the category of the comic emerges, it is loaded with an indescribable beauty.

The rushed rhythm is characterized by the request of several consecutive or concomitant orders, usually on Saturday nights and Sundays, times of great work flow; the rhythm makes them work very fast and sometimes under pressure and stress. On one occasion, Raissa was preparing a dish and began expressing herself: "Go faster, Daniela!" Daniela responds: "I'm doing it as fast as I can!" The cook responds: "But it's not enough, do it faster, if you don't hurry it will be overly done!" Pressure and stress cause some discomfort. It is not characterized as "ugly", but the 
environment lacks beauty and lightness. At such times, the cook community is undermined by the hierarchy that becomes strong, the cooks demand a lot from the kitchen assistants. In these cases, we observe the expression of the agogic aesthetic categories. The rhythm considered as slow, busy and rushed by the researcher, can be represented respectively by the agogic categories of adagio, alegro, moderato e prestíssimo. The rhythm that permeates the kitchen is driven by the restaurant's movements, linked to customer service, the demand for the ordering of dishes, to the cooking time of the dishes. The rhythm is essential for cooking as a practice, allowing the adaptation to the demands of the gastronomic organizations and the preparation and cooking times of the dishes (LOPES, SOUZA, IPIRANGA, 2014; RINK, 2012).

As it was possible to observe, aesthetics is present in all moments of organizational life and their appearance is frequent as the actors learn and transmit cooking as a practice. Knowledge is situated in the body that performs the work practice. In this way, the body acts simultaneously to perform the work practice. Through the five senses, it becomes possible to observe sensible knowledge. In this way, the body can be trained to perform specific activities. By this line of theoretical construction, one understands that it is possible to develop a "good eye", a "good ear", a "good nose", a "good taste" and "good hands" (STRATI, 2007b) to return cooking as practice.

All the aesthetic categories presented so far, reveal ways of perceiving the activities developed in the kitchens of the restaurants surveyed. Therefore, they should not be understood as isolated categories, But expressions of the set of activities that integrate the cooking practice. Under this understanding, it is possible to perceive that the aesthetic categories have some degree of overlap between them that show, in fact, the overlapping of activities that are fundamental to form the cooking practice. Thus aesthetic categories are not the activities nor the practice itself, but an adjectivation of how these activities and the cooking practice were being performed at the time of observation.

\subsection{Social learning and the links with cooking as practice: formation of sensible knowledge}

Learning to cook as a practice, that is, learning the subjective aspects immersed in the action of "doing" happens through the activation of sensible knowledge. Put another way, the locus of knowledge in cooking is in practice. Thus, the body plays a relevant role in the perception and accomplishment of the practice. The body, through the perceptive faculties of sight, hearing, touch, smell, and taste, is the locus where knowledge is concentrated from the individual point of view. Thus, the specificity and the operability of the body give the meaning of experience through the collective 
construction evidenced by the aesthetic judgment (STRATI, 2007a; BERTOLIN, CAPPELLE, BRITO, 2014). That is, in cooking as practice, the manifestation of the locus of knowledge in the individual is manifested by the use of the five perceptive faculties in the construction of a sensible knowledge. Figure 1 demonstrates the main learning functions of the perceptive faculties in the studied context while cooking as practice is performed.

The sense organs are part of the practice because their use occurs as an instrument (GHERARDI, 2013; LOPES, SOUZA, IPIRANGA, 2014) of measure. After the use of perceptive sensory faculties, there is an interpretation that leads to a subsequent decision about an action within the cooking practice, which does not occur in isolation, but is collectively sustained (GHERARDI, 2013).

As far as the tasting faculty is concerned, in addition to being an instrument of measurement, it manifests itself through the dimension of the food culture of a locality, since through the aesthetic judgment the interpretation of taste takes place, and this interpretation is judged on the basis of the social and collective construction of the cooks. In this way, there is a flavor reference understood as "tasty". This collective aesthetic judgment allows the positive and acceptable interpretation of this flavor, collectively recognized as familiar (SOARES, BISPO, 2014; STRATI, 1992, 2007a).

In this case, when the actors share the perception that the regional food is tasty, they do it collectively and, as they share, they also sustain it, that is, they produce and reproduce on the basis of and through aesthetic judgment. And this taste, which in the case of the gastronomic doing it becomes expressed through the taste of food, characterized as regional, it helps to produce and reproduce the society that also experiences this taste (already refined by the cooks) (GHERARDI, 2006, 2014a; AZEVEDO, 2013).

It should be noted that in RI the cooks did not have autonomy granted by the management of the restaurants to create new dishes, which refers to a taste that was institutionalized by management, but was minimally altered in the cooking action depending on the context (number of clients and number of employees) and aesthetic categories (rhythm, tension, comic etc.) dominant on the day. In the RII, the taste was institutionalized by management, but there was greater freedom for the cooks to introduce punctual changes to the dish, which suggests a taste as a non-institutionalized process managerially (GHERARDI, 2014a).

However, in the contexts of the two regional restaurants, perceptive faculties are tools for cooks. While learning to cook as a practice, one also learns the taste, the novice learns a way to carry their body; the experimentation of a taste is fundamental for the sharing of that taste. This 


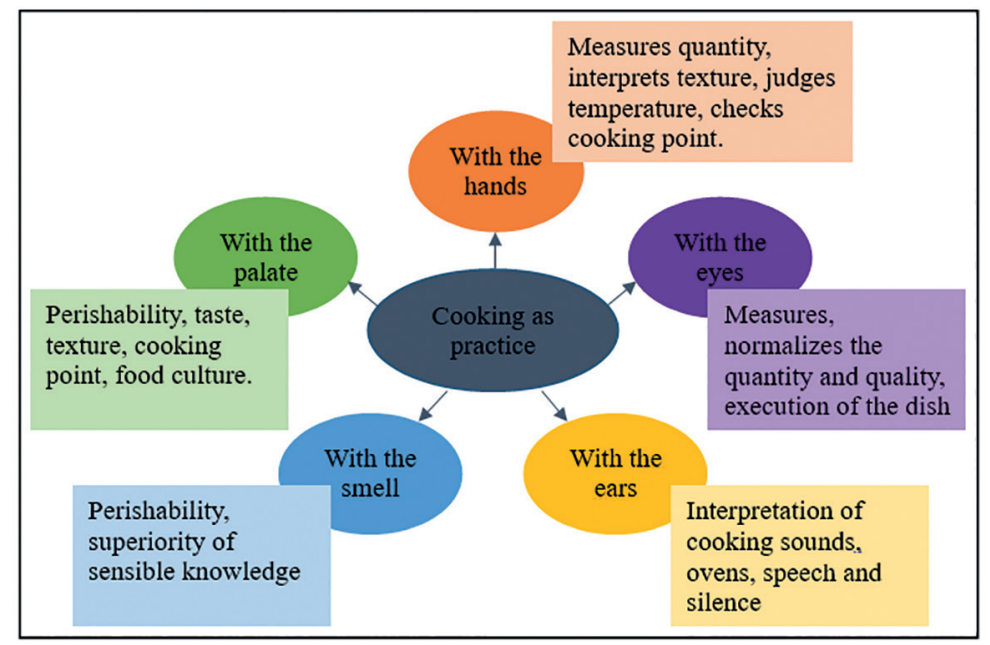

Source: Elaborated by the authors based on field research, 2015.

Figure 1. Use of sensible knowledge in cooking as practice

becomes clear, for example, when the body gets used to the "hot", it is accustomed that hot is part of cooking as practice, for example.

In this way, sensible knowledge happens when the novice enters the organization, begins to live the social experiences in the organization, starts to engage and begins to observe at random how the activities are developed. These random observations happen and, little by little, the novice will have an understanding of the situated curriculum These random observations happen, and little by little, the newcomer will have an understanding of the situated curriculum of what will need to be learned to become a cook recognized as a practitioner in restaurants I and II. Random observations involve learning the use of perceptive faculties according to the norms institutionalized by cooks and management.

When a novice is recognized as someone who can use their perceptive tools according to cooks' standards, their actions change and they begin to build greater confidence to perform other activities. This means that the beginner began to share the aesthetic judgment of the community.

Even so, there are aspects that have not yet become apparent to the novice, which are then shared through directive guidance that occurs while a more experienced actor teaches a novice actor to cook. And the novice is doing and learning while cooking, according to what was explained by the most experienced practitioner. The signal of approval by the most experienced practitioner also corresponds to the legitimacy, as well as the sharing of activities that occur with those who have achieved some degree of legitimation. When beginners seek legitimation without social support, they are ignored. This happens through sensible knowledge as illustrated in figure 2. 
Thus, when entering the kitchen, a novice interacts socially and feels, through the activation of his perceptive faculties, which also involves the feeling apprehension of a collective aesthetic judgment; then one aesthetically judges the bodily impression, not in a particular way, but according to the social and collective construction of the other practitioners; in understanding, the social actor categorizes the feeling expressing the aesthetic category and, based on this, acts performing the activities of the cooking practice, producing and reproducing not only their work but, by extension, society.

When analyzing cooking as a practice in regional restaurants, there are some reflections beyond the researched context that invite us to think theoretically about the organizational aesthetics and the field of organizational studies itself. In relation to the theory of organizational aesthetics, it can be seen that the aesthetic categories are not the activities nor the analyzed practice itself, but indicate how activities and practices are performed individually and collectively.

Thus, through aesthetic categories, it is possible to better understand the dynamics of practices from the emotional and affective point of view so that multiple "rationalities" may be present in the same practice performed at different times. For example, just like cooking, other organizational practices such as decision making, the sale of a product, creativity, among others, present themselves distinctly when aesthetically performed in environments dominated by "tense", the "laid back", or by the "comic". The categories "rhythm" and "synchronism" help to understand the processuality of a practice.

In the scope of organizational studies, through aesthetics, the possibilities of advancing in the understanding of organizational learning are widened, as already presented by several national and international studies, but this also paves the way of how, based on this understanding, to create new forms of dialogue between the formal and informal learning processes in order to support new forms of professional education that would help to overcome the understanding that theory and practice are dichotomous.

\section{CONCLUSION}

The objective of this research was to analyze the learning process of cooking in two regional food restaurants in a capital of the Brazilian northeast in the light of social practices and organizational aesthetics. This objective was achieved when it was discovered that cooks learn to cook using their perceptive faculties and activate their aesthetic judgment. 


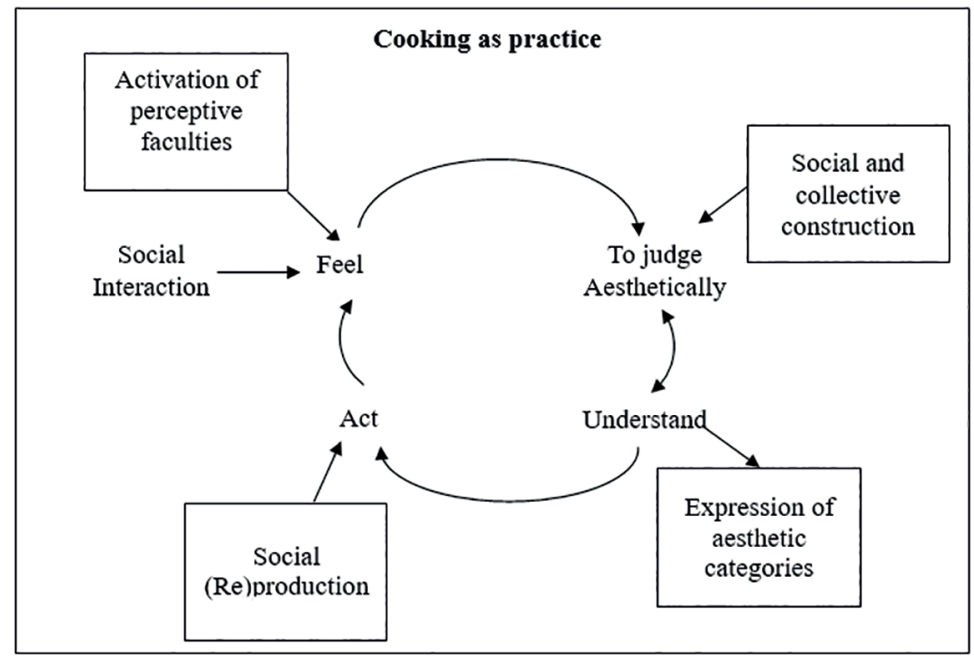

Source: Elaborated by the authors based on field research

Figure 2. Formation of sensible knowledge in cooking as practice

Therefore, the learning process of cooking happens through the legitimation, from random and direct observations; it is through the perceptive faculties that the novice learns. The notion of situated curriculum and the social action to learn how to cook was also efficient in the context. When the novice acquires some legitimation, one begins to act in a way that is judged as aesthetically correct. Transmission is strongly linked to the apprehension of aesthetic judgment. Thus the perceptive faculties are embedded in the process of learning.

Organizational aesthetics is a prominent element in any organization, but in a gastronomic organization these aspects are strengthened, because the very cook's work makes use of the smell, seeing, hearing, feeling and tasting. It is these elements, present in the work environment, that provide the improvement changing and reproducing taste.

We conclude that sensible knowledge is the main knowledge used in cooking as a practice for taste-making; it is in the place of scientific knowledge. Thus, in the labor practice analyzed, there is little evidence of the use of formal education, scientific knowledge and specific technologies. However, we highlight that in many instances, formal education, scientific knowledge and specific technologies were auxiliary to this process. In this case, the perceptive faculty of hearing is evidenced, which depends directly on a scientific technological stimulus to act in certain situations.

It should also be noted that, during the research, some limitations were experienced. The first relates to the access to restaurants - the survey received six negatives - , and this is due to the duration and immersion in the studied organization. The second concerns the field. Commercial establishments are a type of situational territory with its own rules. Thus, respondents participated 
spontaneously, but limited. The actors have the perception that they do things that must be done, otherwise they could be jeopardized because the research was previously approved by the management (GHERARDI, 2014).

Finally, the opportunities for future studies are highlighted: creativity in the practice of cooking; gastronomy as a texture of practices that is shrouded in at least four practices: cooking, eating, food culture and regional cuisine; Social learning of practical training in professional cooks.

\section{REFERENCES}

ANTONACOPOULOU, E. (2015). One more time - what is practice? Teoria e Prática em Administração-TPA, v. 5 n. 2, p. 01-26, 2015.

ARISTOTLE. Nicomacheanethics (trans. Terence Irwin-2 $2^{\text {nd }}$ ed.). Indianapolis: Hackett Publishing, 1999.

AZEVEDO, D. Aprendizagem Organizacional e Epistemologia da Prática: Um Balanço de Percurso e Repercussões. Revista Interdisciplinar de Gestão Social-RIGS, v.2 n.1, 2013.

BASSO, K.; PAULI, J.; BRESSAN, V. P. Relações de gênero e estética organizacional: sugestões para estudos sobre relações, cultura e desempenho. Cadernos EBAPE.BR, v. 12, n. 3, p. 688-688, 2014.

BERTOLIN, R. V.; CAPPELlE, M. C. A.; BRITO, M. J. de. Corporeidade e Estética na Aprendizagem Organizacional: Insights Emergentes. Revista de Administração Mackenzie, v. 15, n. $2,2014$.

BISPO, M. de S. Aprendizagem organizacional baseada no conceito de prática: contribuições de Silvia Gherardi. REV. ADM. Mackenzie, v.14, n..6, p. 132-161. 2013 a.

BISPO, M. de S. Estudos baseados em prática: conceitos, história e perspectivas. Revista Interdisciplinar de Gestão Social, v.2, n.1, p.13-33. 2013 b.

BISPO, M. de S. O Processo de organizar em agências de viagens: influências estéticas, etnometodológicas e práticas. Revista Brasileira de Pesquisa em Turismo, v. 8, p. 161, 2014.

BISPO, M. de S. Methodological Reflections on Practice-Based Research in Organization Studies. Brazilian Administration Review-BAR, v. 12, n. 3, p. 309-323, 2015.

BOURDIEU, P. Outline of a theory of practice. Cambridge: Cambridge Press, 1977.

BOURDIEU, P. The logic of practice. California: Stanford University Press, 1990.

BRANDÃO, E. A. A estética do Marketing. Revista Gestão \& Tecnologia, v. 8, n. 1, art. 6, p. 1-10, 2008.

CERTEAU, M. de. A invenção do cotidiano: 1 . Artes de fazer (3a ed.). Petrópolis, RJ:

Vozes, 1998.EWENSTEIN, B.; WHYTE, J.Beyond Words: Aesthetic Knowledge and Knowing in Organizations, Organization Studies, v.28, n. 5, p. 689-708, 2007.

FERREIRA, J. F.; GODOY, A. S. Processos de Aprendizagem: Um Estudo em Três Restaurantes de um Clube Etnico Alemão de Negócios, Gastronomia e Cultura. Revista de Administração Mackenzie, v. 16, n. 2, p. 15-44, 2015. 
FLACH, L.; ANTONELLO, C. S. Organizações culturais e a aprendizagem baseada em práticas. Cadernos EBAPE, v. 9, n. 1, p. 155-175, 2011.

FINE, G. A. Kitchens: the culture of restaurant work. Berkeley, CA: University of California Press, 1996.

FLICK, U. Uma introdução à pesquisa qualitativa. São Paulo: Bookman, 2009.

GALLON, S.; BITENCOURT, B. M.;VIANA, D. D.; ANTONELLO, C. S. Formas de Aprendizagem e Saberes no Trabalho de Manicures . Revista Pensamento Contemporâneo em Administração, v. 10, n. 1, p. 96-112, 2016.

GHERARDI, S. From organizational learning to practice-based knowing. Human Relations, v.54, n.1, p.131-139, 2001. p. 1- 44.

GHERARDI, S. Practice-based theorizing on learning and knowing in organizations: An introduction. Organization, v.7, n.2, p. 211-223, 2000.

GHERARDI, S. Organizational knowledge: the texture of workplace learning. Oxford: Blackwell, 2006.

GHERARDI, S. Knowing and learning in practice-based studies: an introduction. Learning Organization, v. 16 n. 5, p. $352-359,2009$.

GHERARDI, S. How to conduct a practice-based study: problems and methods. Cheltenham: Edward Elgar, 2012. pp. 155 - 177.

GHERARDI, S. Prática? É uma Questão de Gosto! Revista Interdisciplinar de Gestão Social, v.2, n.1, pp 107-124, 2013.

GHERARDI, S. Conhecimento situado e ação situada: o que os estudos baseados em prática prometem. In: GHERARDI, S.; STRATI, A. Administração e aprendizagem na prática. Rio de Janeiro: Elsevier, 2014a.

GHERARDI, S. O poder crítico da lente das práticas. In: GHERARDI, S.; STRATI, A. Administração e aprendizagem na prática. Rio de Janeiro: Elsevier, $2014 \mathrm{~b}$.

GHERARDI, S.;NICOLINI,D. “Actor-networks:ecology and entrepreneurs”. In: CZARNIAWSKA, B.; HERNES, T. (eds). Actor-Network Theory and Organizing. Copenhagen: Liber \& Copenhagen Business School Press, 2005, p. 285-306.

GHERARDI, S.; NICOLINI, D.; STRATI, A. The passion for knowing. Organization; The Interdisciplinary Journal of Organizationory and Society, v. 14, n. 3, p. 315-329, 2007.

GIDDENS, A. The Constitution of Society. Cambridge: Polity Press, 1984. IPIRANGA, A. S. R.; LOPES, L. L. S.; SOUZA, E. M. A Experiência Estética nas Práticas Culinárias de uma Organização Gastronômica. Organizações \& Sociedade, v. 23, n. 77, p. 191-210, 2016.

HEGARTY, J. A \& O’MAHONY, G. B. Gastronomy: a phenomenon of cultural expressionism and an aesthetic for living. Hospitality Management, v. 20, 3 - 13, 2001.

INFOJOBS. Auxiliar de Cozinha. Disponível em <http://www.infojobs.com.br/artigos/Auxiliar de_Cozinha_2199.aspx> Acesso em 16 de dezembro de 2014.

LATOUR, B. Reassembling the social: an introduction to actor-network-theory. Oxford: Oxford University Press, 2005. 
LAVE, J.; WENGER, E. Situated Learning: legitimate peripheral participation. Nova York: Cambridge University Press, 1991.

LEAL, R. As dimensões da Racionalidade e os Estudos Organizacionais: a mediação entre a modernidade e a pós-modernidade. Organizações \& Sociedade, v. 9, n. 25, p. 77-91, 2002.

LEAL, R.A Estética como Elemento para Compreensão da Criatividade nas Organizações. Organizações \& Sociedade, v. 14, n. 42, p. 67-82, 2007.

LOPES, L. L. S.; SOUZA, E. M. de; IPIRANGA, A. S. R. Desvelando as Categorias Estéticas na Organização de um Pequeno Restaurante. Revista Interdisciplinar de Gestão Social - RIGS, v. 3, p. 207-222, 2014.

MENESES, U. T. B.; CARNEIRO, H. A História da Alimentação: balizas historiográficas. Anais do Museu Paulista: História e Cultura Material, Nova Série, v. 5, p. 9-92, 1997.

MIETTINEN, R.; SAMRA-FREDERICKS, D.; YANOW, D. Re-turn to practice: an introductory essay. Organization Studies, v. 30, n. 12, p. 1309-1327, 2009.

NICOLINI, D. Zooming in and zooming out: a package of method and theory to study work practice. In: YBEMA, S.; YANOW, D.; WELS, H.; KAMSTEEG, F. (Ed.). Organizational ethnography: Studying the complexity of everyday life. London: SAGE Publications, 2009. p. 120-138.

NICOLINI, D. Practice Theory, Work, \& Organization: an introduction. Oxford: Oxford University Press, 2013.

ORLIKOWSKI, W. J. Knowing in practice: enacting a collective capability in distributed organizing. Organization Science, v. 13, n. 3, p. 249-273, 2002.

POLANYI, M. The Tacit Dimension. London: Routledge. 1966.

RECKWITZ, A. Toward a Theory of Social Practices: a development in culturalist theorizing. European Journal of Social Theory, v. 5, n. 2. p. 243-263, 2002.

REED, M. Teorização Organizacional: um campo historicamente contestado. In: CLEGG, Stewart; HARDY, Cynthia; NORD, Walter (Orgs.) Handbook de Estudos Organizacionais. São Paulo: Atlas, 2007. v.1. cap 1, p.61-97.

RINK, John. Manipulando o tempo: ritmo, métrica e andamento nas Fantasias Op. 116 de Brahms. Em Pauta, v. 20, n. 34/35, 2012. p. 245-282.

RODRIGUES, R. A arte para além da Estética: arte contemporânea e o discurso dos artistas. Artefilosofia, 5, 2008. p. 119-131.

SANTOS, L. L. S.; ALCADIPANI, R. Por uma Epistemologia das Práticas Organizacionais: A contribuição de Theodore Schatzki. $O \& S$, v. 22, n. 72, p. 79-98, 2015.

SCHATZKI, T. R. Introduction: practice theory. In: Schatzki, T. R.; Knorr Cetina, K.; Von Savigny, E., (eds.) The Practice Turn in Contemporary Theory. (pp.01-14). New York: Routledge, 2001.

SHOVE, E.; PANTZAR, M.; WATSON, M. The dynamics of social practice: Everyday life and how it changes. London: Sage Publications, 2012.

SOARES, L. C.; BISPO, M. de S. Contribuições da Estética Organizacional para a Pesquisa em

Organizações Gastronômicas. Revista Brasileira de Pesquisa em Turismo-RBTUR, v. 8, n. 3, p. 476-493, 2014. 
STRATI, A. The aesthetic approach in organization studies. 2000. In: LINSTEAD, S.; HÖPFL, H.

(Ed.). The aesthetics of organization. London: SAGE Publications, 2000. pp. 13-34.

STRATI, A.; MONTOUX, P. G. de. Introduction: Organizing aesthetics. Human Relations, v. 55, n. 7, p. 755-766, 2002.

STRATI, A. Aesthetics understanding of organizational life. Academy of Management Review, v. 17, n. 3, p. 568-581, 1992.

STRATI, A. Organização e Estética. Rio de Janeiro: Editora FGV, 2007a. 320 p.

STRATI, A. Organizational artifacts and the aesthetic approach. In: RAFAELI, A.; PRATT, M. (Ed.). Artifacts and Organizations: Beyond mere symbolism. Ahwah, New Jersey: Lawrence Erlbaum Associates, 2006. p. 23-40.

STRATI, A. Sensible knowledge and practice-based learning. Management Learning, v. 38, n. 1, p. $61-77,2007 \mathrm{~b}$.

STRATI, A. Aesthetics understanding of work and organizational life: Approaches and research developments. Sociology Compass, v. 10, n. 4, p. 880-893, 2010.

STRATI, A. "Você faz coisas belas?": estética e arte em métodos qualitativos de estudos organizacionais. In: GHERARDI, S.; STRATI, A. Administração e aprendizagem na prática. Rio de Janeiro: Elsevier, 2014.

TAYLOR, S. S.; HANSEN, H. Finding form: Looking at the field of organizational aesthetics. Journal of Management Studies, v. 42, n. 6, p. 1211-1231, 2005.

VIEIRA, Domingo. Grande diccionario portuguez ou Thesouro da lingua portuguesa. 1878.

WENGER, E. Communities of Practice: learning, Meaning and Identity, Cambidge: Cambridge University Press. 1998.

WILLERDING, I. A. V.; KRAUSE, M. G.; LAPOLLI, E. M. Gestão de pessoas e gestão do conhecimento à luz da estética organizacional em uma organização de base tecnológica. Perspectivas em Gestão \& Conhecimento, v. 6, n. 1, p. 141-154, 2016.

WOOD JR, T.; CSILlAG, P. Estética Organizacional. Organização \& Sociedade, v. 8, n. 21, p. 35-44, 2001. 